\title{
NOTES
}

\section{WAS WHITMAN “BETRAYED” IN BRAZIL?: GEIR CAMPOS, ANA CRISTINA CESAR, AND THE 1983 CHOPPING UP OF LEAVES OF GRASS}

"The idea of translating Whitman's poetry had never crossed my mind . . . the original language of the poet was enough for me to understand and love him well."' But Brazilian poet Geir Campos nevertheless decided to translate Whitman's poetry, and not only once. In 1964, just a few weeks before Brazil fell under the rule of a right-wing military regime, Campos published Fôlhas de Relva, the first substantial selection of poems from Walt Whitman's Leaves of Grass to be translated into Brazilian Portuguese. ${ }^{2}$ Nineteen years later, just two years before the collapse of the twenty-one-year regime, Campos revisited this selection and republished it by tacking on a "leafy pun": Fôlhas de Relva (Leaves of Grass) became Folhas das Folhas de Relva (Leaves of Leaves of Grass) in 1983. ${ }^{3}$

Why did Campos decide that his 1964 Fôlhas de Relva was not "enough to understand and love" the American poet in 1983? Why not simply republish his former translation as it was? In this brief commentary, I offer a new view of Folhas das Folhas de Relva through a reading and critique of "O Rosto, o Corpo, a Voz" ("The Face, the Body, the Voice"), Brazilian poet Ana Cristina Cesar's contemporaneous review of Campos's retranslation. Besides briefly discussing the contribution of Cesar's early critical piece to the reception of Leaves of Grass within the cultural and historical circuits of 1980s Brazil, I also offer, along with USAmerican translator and poet Reginald Gibbons, a translation of " $\mathrm{O}$ Rosto, o Corpo, a Voz" into English for the first time. Such tasks must begin by evidencing how Campos transformed Fôlhas de Relva into Folhas das Folhas de Relva.

The readers who glance through the 1964 and the 1983 editions easily notice what both have in common: the same overall organization and number of poems (twenty-three in total, some complete, others in fragments), displayed according to Whitman's arrangements of clusters and sequences in the 1891- 
1892 final, or "death bed" edition of Leaves of Grass. A more detailed look at them, however, could leave readers bewildered. To start with, and in radical contrast with the 1964 volume, Folhas das Folhas de Relva features Campos's inclusion of extensive paratexts - a pen-and-ink portrait of Whitman drawn by Japanese-descent artist Joji Kussunoki; a biographical note summarizing Campos's life and professional achievements; a preface written by countercultural Brazilian poet Paulo Leminski; a list of other books published in the same series, accompanied by blurbs and reviews; and Campos's own "Esta Tradução" ("This Translation"), a combining of a critical introduction with a quasi-theory of translation that opens with a suggestive epigraph, "I too am untranslatable," Whitman's verse 52 in "Song of Myself."

It is in "Esta Tradução" that Campos attempted an explanation of his second change in the 1983 edition: the title itself. He writes, "this is a translation of selected poems of Leaves of Grass by Walt Whitman which, by parodying the title Flores das 'Flores do Mal' (The Flowers of 'The Flowers of Evil'), quite a find by Guilherme de Almeida for his translation of selected poems of Charles Baudelaire's Fleurs du Mal, could only be titled Folhas das Folhas de Relva" (141). ${ }^{4}$ Campos's play on de Almeida's translation of Baudelaire's original title, as well as on Whitman's and his own in 1964, added more layers to emphasize the rewritings that his 1983 edition had gone through. The reader holding Folhas das Folhas de Relva was left with no doubt that the Leaves of Grass s/he was about to get acquainted with was, for better or for worse, "loose leaves."

The most crucial and substantive change is on the level of poetics. Campos drastically remodeled Whitman's poetry: he rearranged the original syntax and the typographical position of the poems on the page, deleted his old punctuation, added some that was new, used altered typefaces and fonts, and updated, so to speak, Whitman's diction so as to fit it into the 1980s Brazilian countercultural ethos and imaginary. Most blatantly, he dismembered Whitman's stretched-out lines into halves of roughly equal length, rendering the original poems almost unrecognizable. Campos's gesture, in sum, conventionalized-or "remodernized"-the greatest novelty of Whitman's lineation, what Brazilian critic Ivo Barroso has described as his "versicular-liturgical outpouring" (Barroso). ${ }^{5}$

Campos justifies these radical changes in "Esta Tradução" under Czech translation theorist Josef Cermák's rubrics "sous-interpretée" and "sur-interpretée." Folhas das Folhas de Relva, Campos explains, is "an 'over-interpretation' of selected poems and fragments of Walt Whitman's Leaves of Grass . .. whereas the 'under-interpretation' moves the translation toward the writer, the 'over-interpretation' moves it toward the reader." That is, whereas in 1964 
Campos attempted to preserve, as he put it, "what the original has in terms of strangeness" by strictly creating a translational equivalence of Whitman's source language, culture, and poetics, in 1983 he went "beyond-the-limit" and "over-interpreted" the poet by "erasing (Whitman's) exotic characteristics," radically minimizing the 1964 equivalence. ${ }^{7}$

Not convinced by Campos's justification, the Brazilian poet Ana Cristina Cesar-to whom Whitman was an acknowledged forefather and a holistic presence in her works - grabs a pen and writes "O Rosto, o Corpo, a Voz" ("The Face, the Body, the Voice"), the first review of Campos's "leafy choppings-up." Published in the leftist Brazilian newspaper fornal do Brasil just a few weeks after Folhas das Folhas de Relva had made its entrée into the Brazilian cultural landscape in 1983, the review reflects Cesar's strong disapproval of Campos's gesture. She argues, "no goal of popularizing - and no theoretical option concerning translation itself-seems to justify these abrupt choppings-up of the original line that unnecessarily betray the literary intention of the American poet." And, borrowing Portuguese poet Álvaro de Campos's epithets when describing Whitman's verses in his own "Saudação a Walt Whitman"9 "Salute to Walt Whitman"), Cesar is quite direct about what makes Whitman distinctively Whitman, at least formally: "where are the jump-verses, the leap-verses, the spasm-poems for the Brazilian reader-be he erudite or not?."10

It is difficult not to partly agree with Cesar's remarks, especially when form is taken into account. Campos-some might argue-visually updated Leaves of Grass "backward" in Folhas das Folhas de Relva: Whitman's poems appear less idiosyncratic and constrained; and Whitman, in turn, seems a stylistically conservative poet. But rather than "betraying Whitman's literary intention" with his "loose poems" (i.e. translations), as Cesar put it, I read Campos's gesture in 1983 as his attempt to retranslate Whitman's “content" rather than Whitman's "form," a dichotomy that Cesar is somewhat oblivious to in her review, but that Campos himself was quite aware of. Proof of this is the answer he gives to Brazilian scholar Maria Clara Bonetti Paro after being questioned in a personal letter whether Folhas das Folhas de Relva would have met with less success had Whitman's verses not been fragmented: 'I think Whitman's 'content' does not depend on the 'form' of his verse. ..."11

The explanation I have given elsewhere for Campos's assertion that "Whitman's content does not depend on the form of his verse" goes beyond Cesar's remarks concerning formal equivalences in translation. ${ }^{12}$ I have read Folhas das Folhas de Relva as a paragon of what I called inter-creation: a translation practice in which the translator aims at preserving and balancing the 
complexities of the cultural encounter between the source and target languages andtexts while incorporating them into his/her work. What Campos attempted to balance in his inter-created Leaves of Grass was the cultural correspondence that Brazil and the United States shared at that time. Domestically, this correspondence was represented by the 1970s Udigrudi/Marginal subculture; transnationally, by the US hippie life-style and its modes of thought. ${ }^{13}$

As such, Campos's inter-creation of Leaves of Grass was highly revisionist at a political and cultural level. It offered Brazilian readers a tangible imaginative window to the kind of freedom and revolutionary spirit on which they could base their reading and acting during the most ferocious period of Brazil's political history: the military regime (1964-1985). Much like Whitman, the comrade of all rebellious souls, Brazilians could also be libidinous, defiant, subversive, all-encompassing, and gender-inclusive; and much like the United States, Brazil could also be, as Folhas das Folhas de Relva proved, an insurgent, military-free, and youth-based nation. In this way, and here is what Cesar mostly failed to acknowledge in her review, Campos did contribute to globalizing Brazil not only at a linguistic, but also at a cultural and political level.

For political, historical, cultural, and disciplinary reasons, creative encounters of Brazilian writers with Whitman's works in translation such as Campos's have yet to receive serious historical and critical attention in literary and cultural scholarship, both within and outside Brazil. Not to mention the scarce terrain of translations of Whitman's works themselves-his early poems, experimental essays, prefaces, journals, short stories, journalistic series, and all the other editions of Leaves of Grass are still awaiting "translations to come" in Brazil. Given these yet incipient fields, Cesar's unique piece on Campos's 1983 translation is thus remarkable - hence her final comment in "O Rosto, o Corpo, a Voz." "Leafing through" Campos's chopped-up Leaves is indeed "indispensable" to open "a much-needed discussion on translation of poetry" among us, either in Brazil, the U.S., or elsewhere.

PATRÍCIA ANZINI Research Center for Communication and Culture, Universidade Católica Portuguesa 